\title{
EFEKTIFITAS PEMBERIAN PROBIOTIK DALAM PAKAN TERHADAP KUALITAS AIR DAN LAJU PERTUMBUHAN PADA PEMELIHARAAN LELE SANGKURIANG (Clarias gariepinus) SISTEM TERPAL
}

\author{
Bambang Wijaya Kesuma $^{1)}$, Budiyanto ${ }^{2)}$, Bieng Brata ${ }^{3)}$ \\ ${ }^{1)}$ Jurusan Budidaya Perairan Fakultas Pertanian Universitas Ratu Samban \\ ${ }^{2)}$ Jurusan TIP Fakultas Pertanian Universitas Bengkulu \\ ${ }^{3)}$ Jurussan S2 PSDA Fakultas Pertanian Universitas bengkulu
}

\begin{abstract}
ABSTRAK
Budidaya lele sistem terpal atau fiber yang saat ini banyak dikembangkan oleh masyarakat perkotaan karena dapat dilakukan di lahan yang relative sempit. Salah satu jenis lele yang banyak dikembangkan adalah Lele Jenis Sangkurinag (Clarias gariepinus). kendala yang sering dihadapi pad budidaya kolam system terpal di perkotaan adalah kualitas air yang terkadang kurang baik karena volume air yang terbatas. Selain itu masih belum maksimalnya pertumbuhan lele yang dibudidayakan oleh para petani ikan. Salah satu solusi mengatasi permasalahan tersebut adalah dengan pemberian Probiotik pada pakan untuk memperbaiki kecernaan kualitas pakan dan dapat memperbaiki kulitas air. Tujuan penelitian untuk mengetahui pengaruh pemberian Probiotik terhadap kualitas air dan laju pertumbuhan Ikan lele sangkuriang. Penelitian menggunakan Probiotik dengan dosis 0, 2, 4, dan $6 \mathrm{ml}$ per kilogram pakan. Pakan diberikan secara at satiation sebanyak $10 \%$ dari berat tubuh dengan frekuensi tiga kali sehari. Setiap perlakuan dilakukukan pengulangan sebayak 5 kali, Total sampel 4 x $5=20$ unit penelitian. Parameter yang diukur dalam penelitian ini adalah laju pertumbuhan, efesiensi pakan dan kualitas air. Hasil penelitian menunjukkan bahwa Pemberian Probiotik pada pakan tidak berpengaruh nyata terhadap kualitas air, namunberpengaruh sangat nyata terhadap laju pertumbuhan dan efisiensi pakan. Pemberian probiotik $6 \mathrm{ml} / \mathrm{kg}$ memiliki nilai laju pertumbuhan tertinggi yaitu $5,15 \%$ perhari, dan efisiensi pakan $50.49 \%$.
\end{abstract}

Kata Kunci : budidaya, lele, probiotik, pertumbuhan, efisiensi pakan, kualitas air

\section{PENDAHULUAN}

Ikan lele merupakan salah satu komoditas perikanan yang saat ini sedang marak diusahakan oleh masyarakat baik dalam skala besar maupun sekala kecil rumah tangga. Ikan lele merupakan komoditas yang sangat disukai masyarakat demikian juga dengan produk olahannya sangat digemari, hal ini dibuktikan dengan semakin berkembangnya usaha-usaha pengelolaan makanan atau kuliner oleh masyarakat yang berasal dari produk ikan lele baik dalam dalam skala besar dan kecil maupun pengolahan dalam bentuk yang lain.
Pemerintah pada tahun 2005 telah meluncurkan program Revitalisasi Pertanian, Perikanan dan Kehutanan (RPPK). Dilanjutkan oleh Direktorat Jendral Perikanan Budidaya (2014) menetapkan 120 komoditas unggulan perikanan yang bepotensi besar untuk ekspor diantaranya adalah udang, rumput laut, ikan lele , ikan kerapu, ikan nila, ikan gurami, ikan patin, ikan hias dan ikan abalone. Dengan diluncurkannya program ini, diharapkan dapat mengembangkan usaha masyarakat dan berkontribusi secara signifikan terhadap pendapatan dan peluang kerja bagi masyarakat pembudidaya.

Kenyataan di lapangan saat ini telah menunjukkan peningkatan perkembangan 
terhadap budidaya ikan lele. Perkembangan ini di dukung oleh beberapa kemudahan dalam sistem pemeliharaan ikan lele yang relatif sederhana dan dapat dilaksanakan dalam lokasi yang terbatas. Berbeda dengan ikan jenis lain, ikan lele mampu hidup dengan baik dengan kondisi air yang terbatas dan kualitas yang lebih rendah dari yang dibutuhkan ikan budidaya pada umumnya. Sehingga komoditas ikan lele sangat memungkinkan dikembangkan didaerah yang memiliki keterbatasan lahan.

Berkembangnya budidaya lele, ternyata selain meningkatkan pendapatan namun di sisi lain juga memberikan dampak yang kurang baik terhadap lingkungan dimana usaha budidaya lele tersebut dilakukan, terutama sistem budidaya yang dilakukan di lokasi perumahan yang padat penduduknya. Budidaya lele sistem terpal atau fiber yang saat ini dikembangkan oleh banyak masyarakat terutama daerah perkotaan, banyak mendapat komplain dari masyarakat sekitar yang disebabkan munculnya bau yang tidak sedap dari air kolam selama pemeliharaan terutama saat ikan mulai besar dan saat dilakukannya pengurasan kolam saat pemanenan. Jika hal ini terus berlangsung maka bukan tidak mungkin dapat menimbulkan konflik sosial antara pembudidaya dan masyarakat sekitarnya. Selain itu dengan dibuangnya air kolam bekas budidaya lele tersebut ke perairan bebas dilingkungan sekitar juga dapat menyebabkan tercemarnya perairan umum, karena air bekas pemeliharaan lele biasanya dibuang begitu saja ke perairan sekitarnya.

Probiotik adalah makanan tambahan (suplemen) berupa sel-sel mikroorganisme hidup yang memiliki pengaruh menguntungkan bagi hewan inang yang mengkonsumsinya melalui penyeimbangan flora mikroorganisme intestinal dalam saluran pencernaan (Irianto, 2007). Pemberian probiotik pada media pemeliharaan dapat meningkatkan kualitas air (Beauty at al .2012. Berdasarkan uraian tersebut di atas, maka perlu diupayakan usaha untuk meminimalisir dampak yang ditimbulkan dari usaha budidaya ikan lele tersebut. Salah satu upaya yang dapat dilakukan adalah dengan melakukan pemberian probotik dalam pakan yang diberikan

\section{METODE PENELITIAN}

Penelitian ini dilaksanakan pada bulan April - Mei 2015, bertempat di Balai Benih Ikan (BBI) Kota Argamakmur. Alat-alat yang digunakan dalam penelitian ini adalah: Kolam terpal ukuran 1 x 1 meter sebanyak 20 buah, pH meter, DO meter, Termometer raksa, Secchi disk, Timbangan, Mistar ukur, Serokan dan Selang air

Bahan-bahan yang digunakan dalam penelitian adalah Bibit ikan lele sangkuriang ( Clarias gariepinus) ukuran $8 / 12 \mathrm{~cm}$, Probiotik dengan merk dagang Raja Lele yang mengandung Lactobacillus acetobacer, dan Pakan pelet jenis 781-2 dengan komposisi nutrisi sebagai berikut:

Tabel 1. Komposisi Nutrisi Pelet 781-2

\begin{tabular}{lcc}
\hline & Nutrisi & Nilai $\%$ \\
\hline Protein & 33 \\
Lemak & 5 \\
Serat Kasar & 6,87 \\
Abu & 7 \\
Kadar Air & 12 \\
\hline
\end{tabular}

Sumber : brosur kandungan nutrisi pellet 781-2

\section{Rancangan Penelitian}

Penelitian dilakukan secara eksperimental dengan empat perlakuan dan lima ulangan, perlakuan yang diberikan adalah: 
pakan tanpa pemberian probiotik (P0), pakan dengan pemberian probiotik $2 \mathrm{ml} / \mathrm{kg}$ (P1), pakan dengan pemberian probiotik 4 $\mathrm{ml} / \mathrm{kg}(\mathrm{P} 2)$, pakan dengan pemberian probiotik 6 ml/kg (P3). Pakan diberikan $10 \%$ dari bobot badan dan diberikan sebanyak tiga kali dalam sehari (Sunarma, 2004).

Rancangan penelitian yang di gunakan adalah Rancangan Acak Lengkap (RAL) (Gomez dan Gomez, 1995) dengan model matematis sebagai berikut:

$$
\mathrm{Xij}=\mu+\tau \mathrm{i}+\epsilon \mathrm{ij}
$$

Keterangan:

$\mathrm{Xij}=$ Hasil pengamatan pada perlakuan ke-i dan ulangan ke-j

$\mu \quad=\quad$ Rata-rata umum

$\tau \mathrm{i}=$ Pengaruh perlakuan ke- $\mathrm{i}$

$\epsilon \mathrm{ij}=$ Pengaruh faktor random pada perlakuan ke-i dan ulangan ke-j

Persiapan pelaksanaan; Membangun Kolam terpal dengan ukuran 1 x 1 meter sebanyak 20 unit dan dilakukan pengacakan kolam perlakuan secara random, penyiapan media air budidaya seminggu sebelum ikan dilepas dengan memasukkan air sumur kedalam kolam terpal setinggi $75 \mathrm{~cm}$ dan menambah pupuk kandang 200gr per kolam.

Pelaksanaan penelitian; Penelitian dilakukan selama 35 hari dan pengamatan dilakukan setiap 7 hari, setiap kolam diisi dengan ikan sebanyak 100 ekor dan dilakukan penimbangan bobot awal sebelum dilepaskan, pakan diberikan sebanyak 3 kali sehari yaitu jam 09.00, jam 12.00 dan jam 16.00. dengan pemberian pakan $10 \%$ dari bobot badan. Pengukuran kualitas air dilakukan 7 hari sekali meliputi parameter $\mathrm{pH}$, Suhu, DO (Oksigen terlarut), kecerahan dan AmoniakDO (Oksigen Terlarut). Parameter yang diamati untuk mengkaji efektifitas dosis adalah laju pertumbuhan dan efesiensi pakan dengan rincian sebagai berikut:

a. Laju Pertumbuhan
Laju pertumbuhan diukur dengan menghitung bobot badan ikan setiap 7 hari sekali dengan sampling $10 \%$ dari populasi perkolam, penghitungan laju pertumbuhan dilakukan dengan rumus laju pertumbuhan menurut Effendi (1997) yakni:

$$
\begin{aligned}
& \mathrm{g}=\frac{w t-w o}{t} \times 100 \% \\
& \text { Keterangan: } \\
& \mathrm{g} \quad=\text { laju pertumbuhan }(\%) \\
& \mathrm{wo} \quad=\text { bobot biomass pada awal penelitian }(\mathrm{g}) \\
& \mathrm{wt} \quad=\text { bobot biomas pada akhir penelitian }(\mathrm{g}) \\
& \mathrm{t} \quad=\text { lama percobaan (hari) }
\end{aligned}
$$

b. Efisiensi Pakan

Parameter Efesiensi pakan di ukur di akhir masa pemeliharaan dengan rumus Efisiensi pakan menurut Effendi (1997) yakni:

$$
\begin{aligned}
& \mathrm{Ep}=\frac{W t+D-W 0}{F} \times 100 \% \\
& \text { Keterangan: } \\
& \mathrm{Ep} \quad=\text { efisiensi pakan }(\%) \\
& \text { Wo = bobot biomassa ikan pada awal } \\
& \text { penelitian }(\mathrm{g}) \\
& \mathrm{Wt}=\text { bobot biomassa ikan pada akhir } \\
& \text { penelitian }(\mathrm{g}) \\
& \text { D = bobot biomassa ikan yang mati selama } \\
& \text { penelitian (g) } \\
& \mathrm{F} \quad=\text { bobot pakan yang diberikan selama } \\
& \text { penelitian }(\mathrm{g})
\end{aligned}
$$

\section{Analisis Data}

Data yang diperoleh dianalisa dengan uji $\mathrm{F}$ dengan tingkat kepercayaan 95\% dan jika terdapat beda nyata akan dilakukan uji lanjut dengan uji jarak berganda Duncan (Gomez dan Gomez, 1995)

\section{HASIL DAN PEMBAHASAN}

\section{Kualitas Air}

Parameter kualitas air yang diamati meliputi suhu, derajat keasaman $(\mathrm{pH})$, dan oksigen terlarut (DO), kadar amoniak dan kecerahan sesuai standar SNI (2014) untuk budidaya pembesaran lele. Pada saat penelitian berlangsung kisaran parameter kualitas air masih dalam kondisi normal dan layak untuk pemeliharaan lele Sangku- 
riang, secara rinci dapat dilihat pada Tabel

2.

Tabel 2. Kisaran Kualitas Air Media Pemeliharaan Pada Setiap Perlakuan

\begin{tabular}{lcccc}
\hline \multirow{2}{*}{ Parameter yang diukur } & \multicolumn{4}{c}{ Perlakuan } \\
\cline { 2 - 5 } & $\mathrm{P} 0$ & $\mathrm{P} 1$ & $\mathrm{P} 2$ & $\mathrm{P} 3$ \\
\hline Suhu air $\left({ }^{\circ} \mathrm{C}\right)$ & $26.18-28.64$ & $26.16-28.64$ & $26.14-28.52$ & $26.14-28.50$ \\
$\mathrm{pH}$ & $6.5-7.1$ & $6.5-7.2$ & $6.5-7.2$ & $6.5-7.2$ \\
Oksigen terlarut $(\mathrm{mg} / \mathrm{l})$ & $6.4-7.1$ & $6.5-7.9$ & $6.5-7.6$ & $6.6-7.9$ \\
Amoniak $(\mathrm{mg} / \mathrm{l})$ & $0.03-0.07$ & $0.03-0.07$ & $0.03-0.06$ & $0.03-0.06$ \\
Kecerahan $(\mathrm{cm})$ & $27.4-29.4$ & $27.4-29.8$ & $27.4-29.8$ & $27.0-29.8$ \\
\hline
\end{tabular}

Rata-rata suhu air selama penelitian relative stabil kisarannya adalah sekitar $26.14^{\circ} \mathrm{C}-28.64{ }^{\circ} \mathrm{C}$. Menurut SNI (2014) kisaran parameter kualitas air untuk budidaya pembesaran adalah $25^{\circ} \mathrm{C}-30^{\circ} \mathrm{C}$. Jika suhu pemeliharaan kurang dari kisaran (suhu rendah), mengakibatkan aktivitas lele Sangkuriang menjadi rendah dan nafsu makan berkurang, sehingga akan mengakibatkan pertumbuhan lele Sangkuriang menjadi lambat. Menurut Djoko (2006), suhu yang baik untuk budidaya Lele sangkuriang berkisar antara $24-30{ }^{\circ} \mathrm{C}$. Sedangkan Himawan, (2008) Menyatakan bahwa Suhu air optimum dalam pemeliharaan ikan lele sangkuriang secara intensif adalah $25-30{ }^{\circ} \mathrm{C}$.

Nilai $\mathrm{pH}$ air selama penelitian relative stabil di kisaran netral yakni 6.5 - 7.2 Nilai tersebut baik untuk pembesarn ikan lele, karena menurut SNI (2014) pH produktif air untuk pertumbuhan bagi pembesaran lele adalah $6.5-8$. Menurut Svobodova, at al, (1993) Kondisi $\mathrm{pH}$ optimal untuk ikan ada pada kisaran 6.58.5. Nilai $\mathrm{pH}$ di atas 9.2 atau kurang dari 4.8 bisa membunuh ikan.

Kandungan oksigen terlarut (DO) selama penelitian adalah berkisar $6,4-7.9$ $\mathrm{mg} / \mathrm{L}$, kisaran ini masih kategori normal untuk budidayaya lele. Berdasarkan SNI (2014) syarat kandungan DO untuk budidaya pembesaran lele adalah minimal 3 $\mathrm{mg} / \mathrm{L}$. Himawan (2008) menyatakan Umumnya ikan lele hidup normal di lingkungan yang memiliki kandungan oksigen terlarut $4 \mathrm{mg} / \mathrm{l}$.

\begin{abstract}
Kandungan amoniak selama penelitian berkisar antara $0.03-0.07$ $\mathrm{mg} / \mathrm{L}$. kandungan tersebut masih dalam batas toleransi wajar. Menurut SNI (2014) kandungan amoniak maksimal dalam perairan budidaya untuk pembesaran lele adalah $0,1 \mathrm{mg} / \mathrm{L}$. Amoniak akan berakibat akut pada konsentrasi 1.0-1.5 mg/L (Svobodova, at al, 1993). Kecerahan merupakan ukuran transparansi perairan, yang ditentukan secara visual dengan menggunakan Secchi disk. Tingkat kecerahan air selama penelitian berkisar 27,4 $\mathrm{cm}-29,8 \mathrm{~cm}$. Menurut Badan Standarisasi Nasional (2014), tingkat kecerahan air untuk budidaya pembesaran Lele adalah 25 $\mathrm{cm}-30 \mathrm{~cm}$.
\end{abstract}

\section{Efektifitas Probiotik Terhadap laju Per- tumbuhan dan Efesiensi Pakan Laju Pertumbuhan}

Laju pertumbuhan lele sangkuriang rata-rata tertinggi diperoleh dari perlakuan P3 (6 ml), kemudian berturut-turut perlakuan P2 (4 ml) dan P1 (2 ml), dan perlakuan P0 $(0 \mathrm{ml})$. Hasil perhitungan analisa sidik ragam uji $f$ dengan taraf $95 \%$ menunjukkan hasil $F$ hitung lebih besar (>) dari pada $F$ Tabel. Hasil ini berarti menunjukkan bahwa pemberian probiotik memberikan perbedaan yang nyata terhadap laju pertumbuhan lele sangkuriang. Hasil analisis uji jarak berganda Duncan menunjukkan hasil pertumbuhan terbaik dengan nilai tertingggi pada perlakuan P3 dan terendah pada P0 sebagaimana tertera pada Tabel 3. 
Tabel 3. Rata-rata Laju Pertumbuhan Harian Selama Penelitian

\begin{tabular}{cc}
\hline Perlakuan (ml/kg) & Laju Pertumbuhan Harian (\%) \\
\hline P0 (0) & $3.37 \mathrm{a}$ \\
P1 (2) & $3.51 \mathrm{a}$ \\
P2 (4) & $4.90 \mathrm{c}$ \\
P3 (6) & $5.15 \mathrm{c}$ \\
\hline
\end{tabular}

Keterangan: Nilai rata-rata yang diikuti huruf tidak sama berbeda nyata menurut uji jarak berganda Duncan taraf kepercayaan $95 \%$.

Rata-rata bobot lele sangkuriang terus meningkat selama 35 hari pemeliharaan selama penelitian. (Gambar 1). Peningkatan Laju Pertumbuhan individu tertinggi terdapat pada perlakuan dengan pemberian probiotik $6 \mathrm{ml}$ sebesar $5,15 \%$ diikuti dengan perlakuan $4 \mathrm{ml} 4,90 \%$. Sedangkan terendah adalah pada perlakuan tanpa pemberian probiotik sebesar 3,37\%

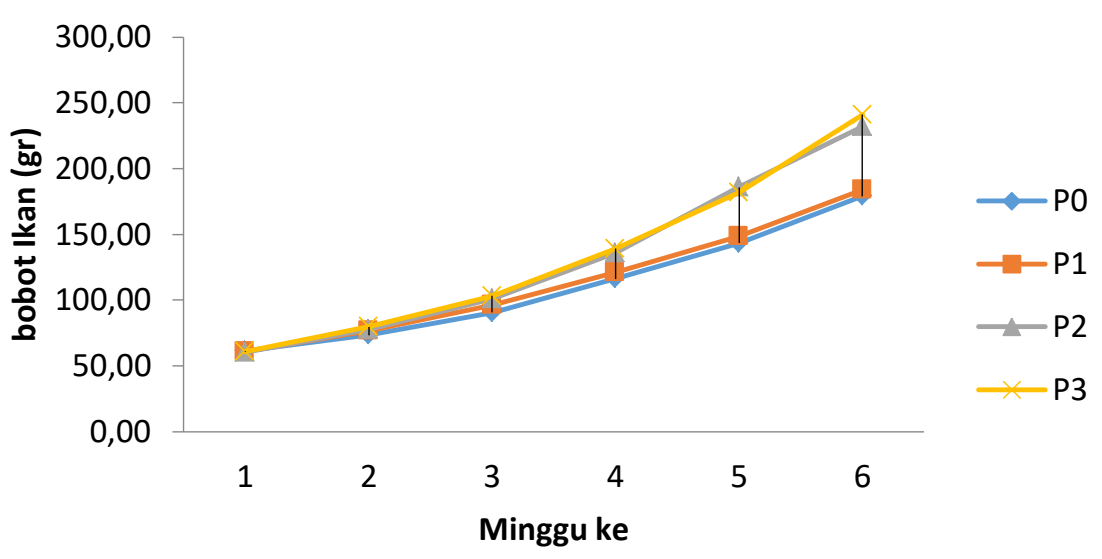

Gambar 2. Grafik bobot ikan lele sangkuriang selama penelitian

Hasil analisis uji F pada taraf $99 \%$ menunjukkan F Hitung > dari F Tabel, berarti pemberian probiotik dalam pakan memberikan perbedaan yang sangat nyata terhadap laju pertumbuhan lele sangkuriang. Uji jarak berganda Duncan menunjukkan bahwa perlakuan P3 adalah nilai laju pertumbuhan yang tertinggi sedangkan nilai laju pertumbuhan terendah pada perlakuan P0 ( Table 3). Peningkatan laju pertumbuhan ini diperkirakan oleh sebab adanya pengaruh bakteri Probiotik dalam pakan, sebagaimana pernyataan Gatesoupe (1999) menyatakan bahwa dengan adanya bakteri Probiotik dalam saluran pencernaan ikan, maka bakteri akan berkompetisi dengan bakteri lain untuk pengambilan nutrisi dan membangun system kekebalan ikan sehingga ikan tersebut tumbuh dan menjadi sehat.

Selain itu (Irianto, 2003) menambahkan bahwa bakteri probiotik tersebut di dalam saluran pencernaan ikan akan mensekresikan enzim-enzim pencernaan seperti protease dan amilase sehingga pakan lebih mudah dicerna serta bakteri tersebut dapat mendominasi di saluran pencernaan ikan dan bakteri-bakteri patogen akan berkurang keberadaannya. Enzim yang disekresikan di dalam saluran pencernaan jumlahnya meningkat juga sesuai dengan jumlah dosis probiotik yang diberikan yang pada gilirannya jumlah pakan yang dicerna juga meningkat. 
Peningkatan daya cerna bermakna pula pada semakin tingginya nutrien yang tersedia untuk diserap tubuh,

\section{Efesiensi Pakan}

Pengamatan terhadap tingkat Efisiensi pakan yang diberikan selama penelitian terhadap seluruh perlakuan berkisar $35,13 \%$ - 50,91 \%, secara rinci terlihat pada Tabel 5. Hasil analisis uji $\mathrm{F}$ pada taraf $99 \%$ menunjukkan $\mathrm{F}$ Hitung > dari F Tabel, berarti pemberian probiotik dalam pakan memberikan perbedaan yang sangat nyata terhadap efisiensi pakan.

Tabel 4. Nilai Efisiensi Untuk Setiap Perlakuan Dan Ulangan

\begin{tabular}{ccccccc}
\hline \multirow{2}{*}{ PERLAKUAN } & \multicolumn{5}{c}{ Efisiensi Pakan(\%) } & \multirow{2}{*}{ Rata-rata } \\
\cline { 2 - 5 } & U1 & U2 & U3 & U4 & U5 & \\
\hline P0 & 34.83 & 35.45 & 34.74 & 33.94 & 34.21 & $34.64 \mathrm{a}$ \\
P1 & 34.36 & 34.29 & 34.47 & 34.03 & 36.55 & $34.74 \mathrm{a}$ \\
P2 & 44.44 & 45.12 & 46.65 & 52.10 & 46.99 & $47.06 \mathrm{~b}$ \\
P3 & 49.62 & 48.03 & 46.69 & 57.72 & 50.40 & $50.49 \mathrm{~b}$ \\
\hline
\end{tabular}
kepercayaan

Keterangan: Nilai rata-rata yang diikuti huruf tidak sama berbeda nyata menurut uji jarak berganda Duncan taraf

Hasil Uji jarak berganda Duncan menunjukkan bahwa perlakuan P3 dengan pemberian probiotik $6 \mathrm{ml} / \mathrm{kg}$ adalah perlakuan dengan nilai efisiensi pakan yang tertinggi yaitu $50.91 \%$ diikuti perlakuan P2 $48.05 \%$, sedangkan nilai efisiensi pakan terendah pada perlakuan P0 35.13\% (Tabel 4). Craig dan Helfrich (2002). Menyatakan bahwa pakan dikatakan baik apabila nilai efisiensi pemberian pakan lebih dari $50 \%$ atau bahkan mendekati 100\%. Berdasarkan pernyataan tersebut maka dari seluruh perlakuan dalam penelitian, perlakuan P3 termasuk dalam kategori memiliki nilai efisiensi pakan yang baik.

Irianto (2003), faktor yang mempengaruhi keberhasilan produk probiotik dalam meningkatkan pertumbuhan dan efisiensi pakan pada ikan yaitu keberadaan bakteri probiotik pada saluran pencernaan ikan. Probiotik masuk ke dalam usus ikan kemudian membantu proses pencernaan sehingga kencernaan meningkat. Kecernaan terhadap pakan meningkat selanjutnya pakan akan lebih efisien dimanfaatkan oleh ikan karena nutrisi pakan akan mudah terserap oleh tubuh yang selanjutnya retensi protein akan meningkat akibat dari penyerapan nutrisi pakan.
Probiotik Raja Lele adalah salah satu jenis Probiotik dengan kandungan bakteri probiotik jenis Lactobacillus acetobacer yang mampu mengubah karbohidrat menjadi asam laktat, kemudian Asam laktat dapat menghasilkan $\mathrm{pH}$ yang lebih rendah. Menurut Buckle at al. (1978) asam laktat dapat menghasilkan $\mathrm{pH}$ yang lebih rendah pada substrat sehingga menimbulkan suasana asam. Dalam keadaan asam lactobacillus sp. memiliki kemampuan untuk menghambat bakteri pathogen dan bakteri pembusuk (Delgado at al., 2001. dalam Rostini, 2007).

\section{KESIMPULAN}

Pemberian probiotik tidak berpengaruh terhadap kualitas air. Namun berpengaruh sangat nyata terhadap laju pertumbuhan dan efesiensi pakan. Pemberian probiotik sebesar $6 \mathrm{ml} / \mathrm{kg}$ pakan menghasilkan laju pertumbuhan Lele sangkuriang tertinggi sebesar $5,15 \%$ dan efisiensi pakan sebesar 50,49\%. Sedangkan tanpa pemberin probiotik laju pertumbuhan sebesar 3,37\% dan efesiensi pakan sebesar $34,64 \%$. 


\section{DAFTAR PUSTAKA}

Buckle, K. A., R. A. Edward, G. H. Fleet and M. Wootan. 1987. Ilmu Pangan. Diterjemahkan oleh H. Purnomo dan Adiono. UI Press, Jakarta.

Craig, S. and Helfrich, L.A. 2002. Understanding Fish Nutrition, Feeds, and Feeding.Virginia State University.Publication 420 - 256

Djoko. 2006. Lele Sangkuriang Alternatif Kualitas di Tanah Priangan. Trobos. Jakarta. Agustus : $80-81$.

Effendi, H. 2003.Telaah Kualitas Air Bagi Pengelolaan Sumberdaya dan Lingkungan Perairan. Kanisius . Jakarta.

Effendi, M.I. 1997, Biologi Perikanan. Yayasan Pustaka Nusatama, Jakarta

Gatesouf, F. J., 1999. The Use Of Probiotics In Aquaculture. Review. Aquaculture. 180:147 - $165 \mathrm{hlm}$.

Gitarani Beauty., Ayu Yustiati., Raffi Grandiosa. 2012. Pengaruh Dosis Mikroirganisme Probiotik Pada Media Pemeliharaan Terhadap Kelangsungan Hidup dan Pertumbuhan benih Ikan Mas Koki (Carassius auratus) dengan Padat Penebaran Yang Berbeda Jurnal Perikanan dan kelautan Volume 3 No 3 Bulan September 2012: 1-6

Gomez, K. A. dan Gomez, A. A. 1995. Prosedur Statistik Untuk Penelitian
Pertanian. Universitas Indonesia, Jakarta

Himawan. 2008. Budidaya Lele Sangkuriang.

http://IndonesiaIndonesia.com/f/18253

-budidaya-lele-sangkuriang-clarias-

sp/. 11.30. 23 Juni 2012 in Agriculture, New Yourk : CAB International, 1997.(diakses 15 april 2018) $1: 1$ kolom

Irianto, A. 2003. Probiotik Akuakultur. Gadjah Mada University Press. Yogyakarta. $125 \mathrm{p}$.

Rostini, I,. 2007, Peran Bakteri Asam Laktat (Lactobacillus plantarum) terhadap masa simpan filet nila merah Pada Suhu rendah. Fakultas Perikanan dan Kelautan. Unpad: Jatinangor

Standar Nasional Indonesia (SNI). 2014. Ikan Lele Dumbo (Clarias sp). Badan Standardisasi Nasional. Jakarta. SNI 6484.3

Sunarma, A. 2004. Peningkatan Produktifitas Usaha Budidaya Lele Sangkuriang (Clarias gariepinus). Balai Budidaya Air Tawar Sukabumi, Jawa Barat.

Svobodova Z, Richard Lioyd, Jana Machova, dan Blanka Vykusova. 1993. Water Quality and Fish Health. EIPAC Technical Paper. FAO Fisheries Department. 